\title{
Arctic Sea Ice Faunal Assemblage: First Approach to Description and Source of the Underice Meiofauna
}

\author{
Andrew G. Carey, Jr. ${ }^{1}$ and P. A. Montagna ${ }^{2}$ \\ ${ }^{1}$ School of Oceanography, Oregon State University, Corvallis, Oregon 97331, USA \\ ${ }^{2}$ Biology Department, University of South Carolina, Columbia, South Carolina 29208, USA
}

\begin{abstract}
The ice meiofaunal assemblage in shallow Stefansson Sound off the northern coast of Alaska included Polychaeta, Nematoda, Rotifera and Crustacea. The crustaceans comprised calanoid copepods, nauplii, 2 species of harpacticoids (Halectinosoma neglectum and Pseudobradya sp.) shared with the benthos and a cyclopoid copepod (Cyclopina gracilis), probably a benthic epiphytic form. Much of the ice meiofaunal assemblage was dominated by larvae and juveniles. The ice taxa were sparse in numbers (100-1,000 times less than the sediments) and depauperate in species (e.g. 2 species of harpacticoids versus 28 in the sediments). The ice meiofauna appears to be derived from both sediments and water column. We hypothesize that during spring the undersurface of nearshore sea ice acts as a substrate for benthic recruitment and for nourishment of a highly selected fauna. However, the meiofauna is too sparse to be significant in the food web or energy budget in the protected nearshore Beaufort Sea.
\end{abstract}

\section{INTRODUCTION}

In polar oceans where sea ice is present over large areas during all or much of the year, invertebrate organisms are associated with the ice-water interface. Algal blooms on the undersurface of the sea ice often occur during the late spring months and have been extensively studied in both the Arctic and Antarctic (reviews: Horner, 1976, 1977). In the Arctic Basin the ice diatoms are mostly pennate (Hsaio, 1980); many species are benthic. They can grow into dense concentrations in the lower several centimeters of ice. A burst of primary production by ice algae can precede the blooms of benthic diatoms in shallow water and phytoplankton in the water column (Matheke and Horner, 1974; Horner, 1977).

An ice fauna has also been reported from scattered and generally casual observations made during ice algal studies. These animals are not well known, and quantitative data are not available. Hypotrichous ciliates, zooflagellates, rhizopods, heliozoans, turbellarians, harpacticoid copepods, gammarid amphipods, polychaete worms, polychaete and cirripede larvae and arctic and polar cods have been reported in associ- ation with the undersurface of sea ice (Barnard, 1959; Mohr and Tibbs, 1963; Andriashev, 1970; Fenchel and Lee, 1972; Horner and Alexander, 1972; Percy, 1975; Golikov and Averincev, 1977; Horner, 1977; Dunbar and Acreman, 1980). Dunbar (unpubl.) states that the invertebrate ice fauna are substrate-seeking forms generally associated with a harder surface, some of which are benthic species. Andriashev (1968) working in the Antarctic found a distinct animal assemblage associated with the sea ice which he called 'true ice animals'.

As very little published information exists on the sea ice fauna, basic relationships with the ecosystem are not well understood. The source and fate of these animals are not known. Are they derived from the benthic or pelagic fauna, or is there an assemblage unique to the ice-water interface? It is thought that the spring ice algal blooms are important as a food source in shallow water to some vertically migrating benthic macrofaunal species (Percy, 1975; Horner, 1976), and to selected meiofauna (Clasby et al., 1976). Furthermore, the epontic ice community may provide a significant input into the coastal or oceanic detrital food web; however, this has not yet been proven (Alexan- 
der, 1980). The geographic extent, and patchiness of the community's distribution has yet to be determined, but the ice algae are potentially an important energy source in the arctic ecosystem.

The present project was undertaken as the start of a program to define the structure of the inshore seasonal sea ice faunal community and its taxonomic and functional relationships to the benthos, zooplankton and nekton beneath. This paper reports the results of the first year's research, a feasibility project designed to sample and identify the meiofauna, especially the harpacticoid copepods. The primary objective was to study the relationships between the ice fauna and the organisms in the sediments beneath. Since all reports of animals associated with the ice substrate indicate the presence of meiofauna (Horner, 1977) and since their small body size obviates large samples, we initially chose to study this ecological group as a segment of the community.

\section{STUDY AREA AND METHODS}

Samples were collected at a station (SS) in Stefansson Sound (Latitude 70 $19.25^{\prime} \mathrm{N}$; Longitude $147^{\circ} 35.1^{\prime} \mathrm{W}$ ) during 9 to 14 March and 18 to 19 May 1979 (Fig. 1). Stefansson Sound is an open, shallow lagoon off the northern coast of Alaska that is protected by a series of gravel barrier islands. It is influenced by the Sagavanirktok River, about $11 \mathrm{~km}$ to the southwest of the station. During the 2 study periods the under-ice water salinity varied from 31.2 to $33.0 \% \mathrm{~S}$, and the bottom-water salinity from 31.4 to $33.1 \%$ S. Water temperatures were nearly constant, ranging from -1.9 to $-2.0^{\circ} \mathrm{C}$ under the ice and from -1.6 to $-2.0^{\circ} \mathrm{C} 1 \mathrm{~m}$ above the sediments. Water depth was 5.2 to $5.5 \mathrm{~m}$. The sediment was heterogeneous and patchy, with scattered cobbles and boulders resting on stiff consolidated mud. Patches of soft, clayey silt were present in depressions and in the lee of rocks.

In the nearshore region of the Arctic Ocean the sea ice is seasonal. Generally, each year freezing begins in September, and the ice lasts until break-up in early June. It attains a maximum thickness of 1.5 to $2.0 \mathrm{~m}$ (Kovacs and Mellor, 1974) and is covered with snow of varying thickness. The snow cover has been demonstrated to be the major factor controlling light transmission to the underice environment (English, 1961; Clasby et al., 1976). During the spring growing season the light energy reaching the ice-water interface gradually increases due both to the increasing solar radiation and to reduced snow cover on the ice surface (Matheke and Horner, 1974).

All samples from the ice and sediments beneath were taken by handheld apparatus operated by SCUBA divers. Random ice samples were routinely taken throughout the study by pushing a $3.5 \mathrm{~cm}$ diameter (i.d.) plastic core tube up through the soft ice layer to the hard ice above. Seventeen cores were taken in March, 1979 and 9 in May, 1979. The sea floor immediately beneath the ice cores was sampled with a $50 \mathrm{~cm}^{3}$ plastic syringe barrel modified into a small piston coring device with an i.d. of $2.9 \mathrm{~cm}$. The patchy soft sediment was sampled randomly with 10 cores taken each field trip. The consolidated clay could not be adequately sampled as coring tubes would not pene-

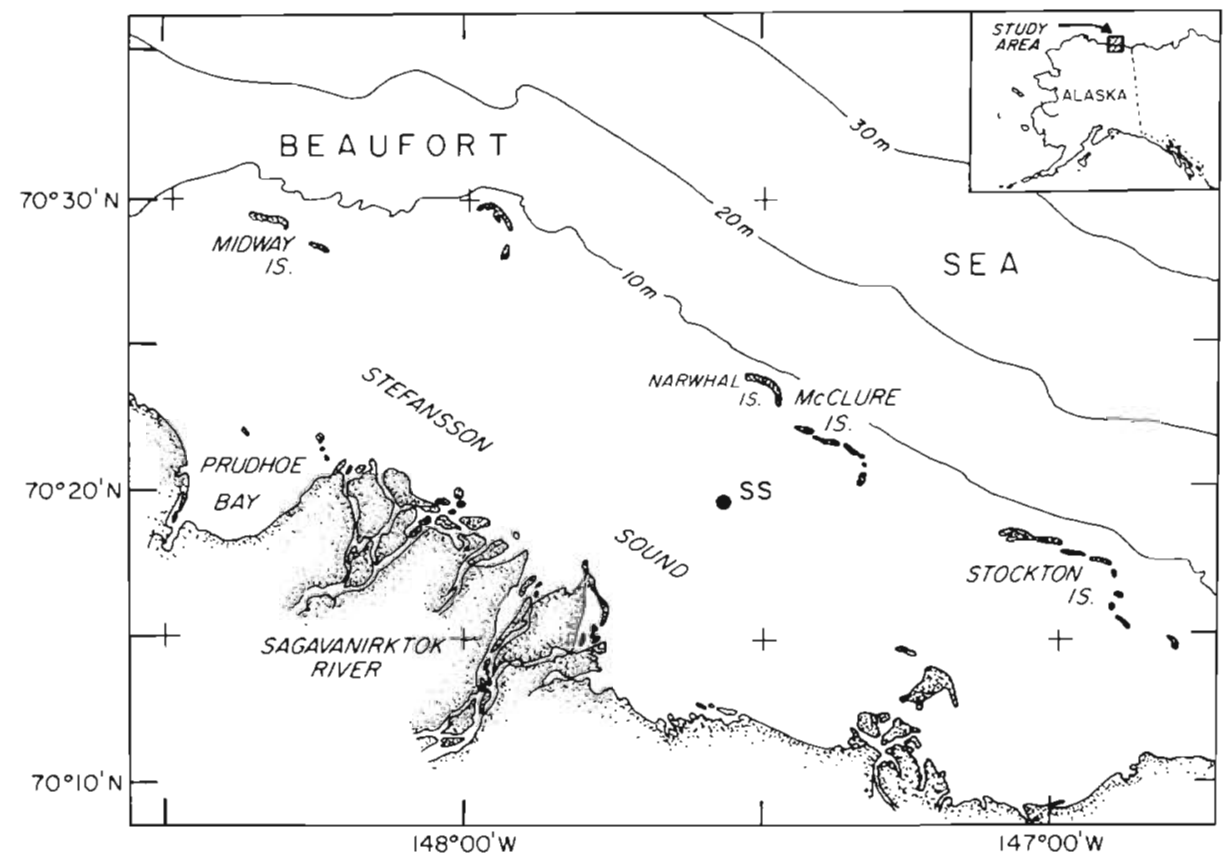

Fig. 1. Location of 1979 winter studies station (SS) in Stefansson Sound, Beaufort Sea (Arctic Ocean) 
trate this substrate even with considerable impact force.

Sampling in March 1979 was before the algal bloom began, and during May 1979 was near the height of ice algal growth. The ice at the March site contained observable concentrations of sediment particles in soft ice billows. The physics of these ice formations and the sedimentation processes incorporating particles within the ice are not understood at this time (Barnes et al., 1979). This form of soft ice, though often widespread in coastal waters, is patchy and is thought to be anomalous. At the time of the May field trip there were no ice algae at the March ice sampling site; this appears to have been caused by the marked shading effect of particulate material incorporated within the ice. Therefore, the second sampling series was moved $200 \mathrm{~m}$ to the southwest where the ice was cleaner and an algal bloom could be observed. The second location, while covered by a different type of ice, was over the same bottom habitat with scattered boulders covered with macrophytes and fine, soft sediments patchily distributed on the consolidated mud.

The ice samples were washed on a $63 \mu \mathrm{m}$ sieve in a heated hut at the ice station. Sediment samples were mixed in toto with preservative; all samples were preserved with $10 \%$ formalin buffered with sodium borate and were stained with Rose Bengal. In the laboratory the meiofauna were picked under a dissecting microscope and sorted into major taxonomic groups. The copepods from the sediments and ice were identified by the second author.

\section{RESULTS}

At Station SS in Stefansson Sound the meiofauna associated with the sediments were abundant and diverse (see Table 1). Total densities averaged $584,300 \mathrm{~m}^{-2}$. During both March and May nematodes were the most abundant taxon ( $90 \%$ of total numbers) with harpacticoid copepods as second most abundant (3-5\%). Small polychaetes were third in abundance $(3 \%)$.

In contrast, the sea ice meiofauna were sparse in number of individuals and taxa (Table 2). The fauna consisted of few taxonomic groups, i.e. copepods, nematodes, rotifers, polychaetes (larvae) and crustaceans (nauplii). Gross taxonomic composition and relative abundance of the fauna changed markedly from the first to the second sampling period. Nematodes were rare in March (about $60 \mathrm{~m}^{-2}$ ) but more abundant in May (about 3,400 $\mathrm{m}^{-2}$ ) comprising $76.9 \%$ of the meiofaunal community. Polychaete larvae were abundant in March (about 5,380 $\mathrm{m}^{-2}$ ), but were not found in the May cores. Crustacean nauplii were collected at both times, $1,770 \mathrm{~m}^{-2}$ in March and $230 \mathrm{~m}^{-2}$ in May. Calanoid copepods were present in the ice core samples in March $\left(610 \mathrm{~m}^{-2}\right)$ but not May, while the cyclopoids were lacking in March, but had become the second most abundant by May $\left(580 \mathrm{~m}^{-2}\right)$.

A 1 -way MANOVA analysis with 16 dependent variables (species) and 1 independent variable (date: March and May) (Wilks F = 3.606, $P=0.159$ ) demonstrated that the sediment meiofauna did not change

Table 1 Sediment meiofauna $(>63 \mu \mathrm{m})$. Numerical density at Station SS, Stefansson Sound (Beaufort Sea). Collection by small core $(2.9 \mathrm{~cm}$ i.d. $)$

\begin{tabular}{|c|c|c|c|c|c|}
\hline \multirow{2}{*}{$\begin{array}{l}\text { Group } \\
\text { Nematoda }\end{array}$} & $\begin{array}{c}\text { March } 1979 \\
(\overline{\mathrm{x}} \pm \mathrm{SD}) 10^{2} \mathrm{~m}^{-2}\end{array}$ & \multirow[b]{2}{*}{90.1} & \multicolumn{2}{|c|}{$\begin{array}{c}\text { May } 1979 \\
(\overline{\mathrm{x}} \pm \mathrm{SD}) 10^{2} \mathrm{~m}^{-2}\end{array}$} & \multirow{2}{*}{$\frac{\%}{90.2}$} \\
\hline & $5,460.8 \pm 3,245.7$ & & $5,071.9 \pm$ & 671.2 & \\
\hline Harpacticoida & $204.2 \pm \quad 75.6$ & 3.4 & $253.3 \pm$ & 124.3 & 4.5 \\
\hline Polychaeta & $192.8 \pm 181.8$ & 3.2 & $169.9 \pm$ & 140.2 & 3.0 \\
\hline Crustacea (nauplii) & $119.3 \pm 105.3$ & 2.0 & $39.2 \pm$ & 43.0 & 0.7 \\
\hline Ostracoda & $60.5 \pm 40.1$ & 1.0 & $0.0 \pm$ & & 0 \\
\hline Kinorhyncha & $11.4 \pm$ & 0.2 & $11.4 \pm$ & 13.4 & 0.2 \\
\hline Tanaidacea & $3.3 \pm$ & $<0.1$ & $65.4 \pm$ & 75.5 & 1.2 \\
\hline Nemertinea & $3.3 \pm$ & $<0.1$ & 0.0 & & 0 \\
\hline Acarina & $3.3 \pm$ & $<0.1$ & 0.0 & & 0 \\
\hline Amphipoda & $1.6 \pm$ & $<0.1$ & 0.0 & & 0 \\
\hline Cumacea & 0.0 & 0 & $6.5 \pm$ & 11.4 & 0.1 \\
\hline Isopoda & 0.0 & 0 & $1.6 \pm$ & 5.2 & $<0.1$ \\
\hline Pelecypoda & 0.0 & 0 & $1.6 \pm$ & 5.2 & $<0.1$ \\
\hline Gastropoda & 0.0 & 0 & $1.6 \pm$ & 5.2 & $<0.1$ \\
\hline Priapulida & 0.0 & 0 & $1.6 \pm$ & 5.2 & $<0.1$ \\
\hline Anthozoa & 0.0 & 0 & $1.6 \pm$ & 5.2 & $<0.1$ \\
\hline Totals $\left(\mathrm{m}^{-2}\right)$ & 606,050 & & 562 & & \\
\hline
\end{tabular}


Table 2. Sea ice meiofauna $(>63 \mu \mathrm{m})$. Numerical densities at Station SS, Stefansson Sound (Beaufort Sea). Collection by small core $(3.5 \mathrm{~cm}$ i.d.)

\begin{tabular}{|c|c|c|c|c|}
\hline Group & $\begin{array}{c}\text { March } 1979 \\
(\bar{x} \pm \text { SD }) 10^{2} \mathrm{~m}^{-2}\end{array}$ & $\%$ & $\begin{array}{c}\text { May } 1979 \\
(\bar{x} \pm \text { SD }) 10^{2} \mathrm{~m}^{-2}\end{array}$ & $\%$ \\
\hline Nematoda & $0.6 \pm 2.5$ & 0.7 & $34.6 \pm 25.9$ & 76.9 \\
\hline Polychaeta (larvae) & $53.8 \pm 53.3$ & 67.3 & 0.0 & 0 \\
\hline \multicolumn{5}{|l|}{ Crustacea } \\
\hline nauplii & $17.7 \pm 19.4$ & 22.1 & $2.3 \pm 4.6$ & 5.1 \\
\hline Copepoda - Harpacticoida & $1.2 \pm 3.4$ & 1.5 & $2.3 \pm 4.6$ & 5.1 \\
\hline Cyclopoida & 0.0 & 0 & $5.8 \pm 7.6$ & 12.9 \\
\hline Calanoida & $6.1 \pm 12.2$ & 7.6 & 0.0 & 0 \\
\hline Rotifera & $0.6 \pm 2.5$ & 0.7 & 0.0 & 0 \\
\hline Totals $\left(m^{-2}\right)$ & 8.000 & & 4,500 & \\
\hline
\end{tabular}

overall from March to May sampling periods. However, there were significant differences between sampling periods for 2 individual benthic taxa (univariate $F$-tests), Tanaidacea $(F=12.086, P=0.003)$ and Ostracoda ( $F=43.984, \mathrm{P}=0.0001)$. Significant overall differences in the ice fauna between the 2 sampling dates was demonstrated by a 1-way MANOVA analysis with 7 dependent variables (species) and 1 independent variable (date: March and May) (Wilks $F=16.984, P=0.0001$ ). There was a significant increase in nematode $(F=48.611, P=0.0001)$ and cyclopoid $(\mathrm{F}=11.539, \mathrm{P}=0.002)$ numbers and $\mathrm{a}$ significant decrease in polychaete $(F=32.391, P=$ $0.0001)$ and nauplii $(F=5.847, P=0.024)$ numbers

Table 3. Three-way ANOVA for long-transformed numbers of individuals of nematoda, harpacticoid copepoda and crustacean nauplii

\begin{tabular}{|lrc|}
\hline Source of variation & F & P \\
\hline Substrate type & 239.2 & .00001 \\
Date & 0.5 & .48576 \\
Taxon & 96.6 & .00001 \\
Substrate type by date & 12.3 & .00083 \\
Substrate type by taxon & 23.4 & .00001 \\
Date by taxon & 2.7 & .07536 \\
Substrate type by date by taxon & 0.6 & .56218 \\
\hline
\end{tabular}

associated with the ice. These univariate F-tests did not demonstrate significant differences in rotifer, harpacticoid or calanoid numerical densities between March and May. An overall comparison of the ice and sediment fauna, undertaken by a 3-way ANOVA for log-transformed numbers of nematodes, harpacticoids, and nauplii, demonstrated significant differences between the sediment and ice fauna densities for both sampling dates (Table 3 ). In spite of the changes in numerical densities for nematodes and nauplii between the March and May sampling efforts, substrate effects were the greatest.

The ice fauna consisted of many juvenile forms. Though copepods were scarce in March, there were many crustacean naupliar stages and polychaete larvae (Table 2). In May, $89 \%$ of the cyclopoid Cyclopina gracilis were copepodites, whereas only $57 \%$ of the sediment harpacticoids were at this stage of development. The number of species and abundance of harpacticoid and cyclopoid copepods were larger in the benthic meiofaunal community and were drastically reduced in the ice substrate assemblage (Table 4 ). Twenty-eight species were present in the sediments during the spring of 1979 . The dominant benthic harpacticoid species were Halectinosoma sp., Bradya typica, Danielssenia stefanssoni and 2 undescribed species: Ameira sp. and Haloschizopera sp. Twenty of the 28 harpacticoids were undescribed species previously not encountered in our offshore studies (Montagna and Carey, 1978). The ice meiofauna contained only 2 species of benthic harpacticoids, Halectinosoma neglectum and Pseudobradya sp., and 1 species of cyclopoid copepod, Cyclopina gracilis.

\section{DISCUSSION}

The benthic meiofaunal community in Stefansson Sound is similar in gross taxonomic composition and numerical density to shallow soft bottom environments elsewhere (Mare, 1942; McIntyre, 1969; Coull and Bell, 1979). However, the ice meiofauna is neither abundant nor speciose (Tables 2 and 3). Numerical density on the ice averaged about 6,200 individuals $\mathrm{m}^{-2}$ versus $584,000 \mathrm{~m}^{-2}$ in the sediments. Few organisms were associated with the ice undersurface, and only a small segment of the meiobenthic population inhabited the ice. Pelagic forms associated with the ice canopy included larvae and calanoid copepods. There- 
Table 4. Substrate copepod (families and species). Summary for ice and sediment cores taken in March and May 1979 at Station SS, Stefansson Sound (Beaufort Sea)

\begin{tabular}{|c|c|c|c|c|c|}
\hline \multirow[b]{2}{*}{ Group } & \multicolumn{2}{|c|}{ March 1979} & \multicolumn{3}{|c|}{ May 1979} \\
\hline & $\begin{array}{c}\text { Sediment } \\
(\mathrm{x}: \mathrm{SD}) 10^{2} \mathrm{~m}^{-2} \\
(\mathrm{~N}=10)\end{array}$ & $\begin{array}{c}\text { Ice } \\
(\overline{\mathrm{x}} \pm \mathrm{SD}) 10^{2} \mathrm{~m}^{-2} \\
(\mathrm{~N}=17)\end{array}$ & $\begin{array}{r}\text { Sedime } \\
(\bar{x} \pm \mathrm{SD}) 1 \\
(\mathrm{~N}=1\end{array}$ & $\begin{array}{l}\text { ent } \\
0^{2} \mathrm{~m}^{-2} \\
0)\end{array}$ & $\begin{array}{c}\text { Ice } \\
(\overrightarrow{\mathrm{x}} \pm \mathrm{SD}) 10^{2} \mathrm{~m}^{-2} \\
(\mathrm{~N}=9)\end{array}$ \\
\hline \multicolumn{6}{|l|}{ Harpacticoida } \\
\hline \multicolumn{6}{|l|}{ Ectinosomatidae } \\
\hline Halectinosoma neglectum (Sars) & $1.6 \pm 5.2$ & $1.2 \pm 3.4$ & $1.6 \pm$ & 5.2 & 0.0 \\
\hline Halectinosoma sp. E & $1.6 \pm 5.2$ & 0.0 & 0.0 & & \\
\hline Halectinosoma sp. F & $39.2 \pm 29.0$ & 0.0 & $66.9 \pm$ & 75.6 & 0.0 \\
\hline Halectinosoma sp. G & $6.5 \pm 8.4$ & 0.0 & $0.0^{-}$ & & 0.0 \\
\hline Bradya typica Boeck & $22.9 \pm 22.1$ & 0.0 & $80.1 \pm$ & 63.7 & 0.0 \\
\hline Pseudobradya sp. B & $1.6 \pm 5.2$ & 0.0 & $1.6 \pm$ & 5.2 & 0.0 \\
\hline Pseudobradya sp. C & $3.3 \pm 6.9$ & 0.0 & $1.6 \pm$ & 5.2 & $2.3 \pm 4.6$ \\
\hline \multicolumn{6}{|l|}{ Tachidiidae } \\
\hline Danielssenia stefanssoni Willey & $21.2 \pm 18.9$ & 0.0 & $9.8 \pm$ & 31.0 & 0.0 \\
\hline \multicolumn{6}{|l|}{ Harpacticidae } \\
\hline Harpacticus flexus Brady \& Robertson & $1.6 \pm 5.2$ & 0.0 & 0.0 & & 0.0 \\
\hline \multicolumn{6}{|l|}{ Tisbidae } \\
\hline Tisbe sp. A & 0.0 & 0.0 & $1.6 \pm$ & 5.2 & 0.0 \\
\hline Zosime sp. A & 0.0 & 0.0 & $1.6 \pm$ & 5.2 & 0.0 \\
\hline \multicolumn{6}{|l|}{ Disoaccidae } \\
\hline Stenhelia nuwukensis M. S. Wilson & $3.3 \pm 10.3$ & 0.0 & $6.5 \pm$ & 11.4 & 0.0 \\
\hline Stenhelia sp. C & $3.3 \pm 6.9$ & 0.0 & 0.0 & & 0.0 \\
\hline Stenhalia sp. E & 0.0 & 0.0 & $3.3 \pm$ & 6.9 & 0.0 \\
\hline Stenhelia sp. P & $1.6 \pm 5.2$ & 0.0 & 0.0 & & 0.0 \\
\hline Amphiascoides sp. A & $3.3 \pm 6.9$ & 0.0 & $8.2 \pm$ & 11.6 & 0.0 \\
\hline Paramphiascella fulvofasciata Rosenfield \& Coull & $16.3 \pm 18.9$ & 0.0 & 0.0 & & 0.0 \\
\hline Haloschizopera sp. A & 0.0 & 0.0 & $40.8 \pm$ & 54.6 & 0.0 \\
\hline \multicolumn{6}{|l|}{ Ameiridae } \\
\hline Ameira sp. A & $53.9 \pm 48.7$ & 0.0 & $17.9 \pm$ & 17.9 & 0.0 \\
\hline Ameirid B & 0.0 & 0.0 & $3.3 \pm$ & 6.9 & 0.0 \\
\hline \multicolumn{6}{|l|}{ Cylindropsyllidae } \\
\hline Cylindropsyllid A & 0.0 & 0.0 & $1.6 \pm$ & 5.2 & 0.0 \\
\hline \multicolumn{6}{|l|}{ Cletodidae } \\
\hline Cletodes tenuipes T Scott & $13.1 \pm 20.1$ & 0.0 & $1.6 \pm$ & 5.2 & 0.0 \\
\hline Cletodes sp. A & $1.6 \pm 5.2$ & 0.0 & 0.0 & & 0.0 \\
\hline Cletodes sp. B & $1.6 \pm 5.2$ & 0.0 & 0.0 & & 0.0 \\
\hline Rhizothrix sp. A & $3.3 \pm 6.9$ & 0.0 & $1.6 \pm$ & 5.2 & 0.0 \\
\hline Eurycletodes sp. A & $1.6 \pm 5.2$ & 0.0 & 0.0 & & 0.0 \\
\hline \multicolumn{6}{|l|}{ Laophontidae } \\
\hline Echinolaophonte brevispinosa (Sars) & $1.6 \pm 5.2$ & 0.0 & $1.6 \pm$ & 5.2 & 0.0 \\
\hline Laophontid A & 0.0 & 0.0 & $1.6 \pm$ & 5.2 & 0.0 \\
\hline \multicolumn{6}{|l|}{ Cyclopoida } \\
\hline Cyclopina gracilis Claus & 0.0 & 0.0 & 0.0 & & $5.8 \pm 6.9$ \\
\hline Total $\left(\mathrm{m}^{-2}\right)$ & $204.0 \pm 75.6$ & $1.2 \pm 3.4$ & $253.3 \pm 1$ & 124.3 & $8.1 \pm 6.9$ \\
\hline
\end{tabular}

fore, the ice meiofauna in the protected sounds and lagoons of the Beaufort Sea is not unique. Its gross taxonomic composition suggests that it is derived from both the water column and the sediments.

Because the sampling location in May had to be moved a short distance from the March site, we cannot be certain if the differences in the epontic community were due to seasonal reproductive events and migrations or were merely a reflection of the different ice substrates. However, the extensive changes in taxonomic composition from March to May and the pre- sence of early growth stages hint at a dynamic meiofaunal assemblage. Harpacticoid copepods, for example, were associated with the ice in greater numbers in March than in May, while the cyclopoid Cyclopina gracilis was collected from the ice only in May. Many of the crustaceans and polychaetes were pelagic juveniles which could have been attracted by the greater light intensities at the ice-water interface, by the ice algae as a food source, or by the substrate itself during their metamorphosis into bottom-living juveniles. 
The ice undersurface appears to be a recruitment ground for certain benthic meiofaunal early life history stages. Polychaete larvae were present in the epontic ice environment in March but not May. The larvae were mainly (93\%) an undescribed species (gen. nov.) in the family Hesionidae (Ruff, unpubl.). The adults of this species have been collected across the $\mathrm{S}$. W. Beaufort Sea continental shelf at depths between 5 to $100 \mathrm{~m}$ (Carey and Ruff, unpubl.). The specimens collected in the ice cores included nectochaetes (larval forms that can swim or crawl) and the early nonswimming juvenile stage. No late juveniles and adults were encountered. A lecithotrophic planktonic larval development has been reported for similar small species of hesionids (Thorson, 1946; Blake, 1975). In general, the smaller hesionid species feed on diatoms (Fauchald and Jumars, 1979), and the nectochaetes and juveniles of 1 such species (Ophiodromus pugettensis) have been observed to ingest diatoms under laboratory conditions (Blake, 1975). Apparently, nectochaetes and juveniles of the new species settle out on the ice undersurface as well as on the sediments; they feed on algae on the ice and - as they grow - fall from the ice and sink to the bottom.

Though Cyclopina gracilis was collected only from the ice during the present study, it has been reported as an epiphytic form elsewhere (Sars, 1918). Since dense populations of the arctic kelp Laminaria solidungla are prevalent on rock surfaces in the study area (Broad, 1979), C. gracilis may normally live on this plant substrate. Horner (1981 and pers. comm.) collected it in the water column near the bottom at Station SS during the 1979 project.

\section{Colonization}

While it is not known how the benthic meiofauna become incorporated in the ice, it seems likely that advective forces are the primary mechanism of transport for these small organisms just as they seem to be for the horizontal movement of meiofauna in shallow waters (Bell and Sherman, 1980; Sherman and Coull, 1980). The harpacticoids and cyclopoids also may swim (Hauspie and Polk, 1973) and may undergo diel or seasonal vertical migrations related to predator avoidance (Andriashev, 1968), reproduction or feeding. The species collected on the ice could themselves migrate the intervening $5 \mathrm{~m}$ or could migrate short distances that would then expose them to mixing forces within the water column. The amounts of sediment and organic detritus within the sea ice over the inner continental shelf suggest strong advective forces in the Beaufort Sea.

The occurrence and composition of ice meiofauna offshore over deep water pose other problems because of the large separation between the ice and sediment assemblages. Here the fauna may be recruited from the pelagic fauna or possibly some few meiofaunal species may preferentially and permanently be associated with the ice substrate. Barnard (1959) reported large numbers of pelagic gammarid amphipods associated with the undersurface of the year-round polar pack ice in the Arctic Basin. In the soft, lower horizon of antarctic seasonal sea ice Fenchel and Lee (1972) reported substrate-type ciliate species that appear to live among the ice crystals in a fashion similar to benthic interstitial microfauna in marine sands. If these or other species are permanently associated with pack ice, they may be ecologically analogous to the 'pseudobenthos' associated with floating sargassum weed over deep water in the Sargasso Sea (Hentschel, 1922; Hesse et al., 1951).

\section{Significance}

We expected the total numbers of meiofauna to increase in response to the increased ice algal standing stock during spring, but only the nematodes increased significantly, possibly as a response to the food source. Links between epontic algae and macrofaunal grazers have been suggested, though the observations are scattered and often anecdotal (English, 1961; Apollonio, 1965; Horner and Alexander, 1972; Horner, 1977). Nematodes and copepods have also been reported as feeding on the microalgae (Clasby et al., 1976). The ice algal standing stocks (cells $\mathrm{l}^{-1}$ ) in Stefansson Sound were markedly different between the March and May sampling periods (Horner, 1981). Total cell concentrations of ice diatoms, flagellates, cryptomonads, Chrysophyta, Euglenophyta, Chlorophyta and Pyrrophyta were $38 \times 10^{3}$ cells $l^{-1}$ in March and $23 \times 10^{6}$ cells $1^{-1}$ in May. As the May location for ice algae was also moved a short distance, it is not possible to state unequivocally that the increase in ice algal cell concentrations was caused by population growth during the season. However, data from elsewhere in the Alaskan area strongly indicate that such growth takes place in situ (Alexander, 1974; Clasby et al., 1976). This growth on the ice undersurface usually precedes the phytoplankton bloom (Matheke and Horner, 1974); in May 1979 the ice algal primary production ( $\mathrm{mg} \mathrm{C} \mathrm{m} \mathrm{m}^{-2} \mathrm{~h}^{-1}$ ) at Station $\mathrm{SS}$ was approximately twice that of the water column (Horner, 1981).

The ice environment forms a substrate that concentrates biological activities at the water-ice interface. Environmental conditions support an intense but patchy algal bloom. The role of ice algae within the arctic ecosystems is potentially important (Alexander, 1974). After the long, dark winter, this is an early 
source of energy for the grazers and a later source upon ice melt for the pelagic and benthic fauna beneath. Intuitively, the abundant epontic diatoms should fall to the sea floor during the melting season and provide a significant nutritional source to the benthos before blooms of phytoplankton and benthic diatoms take place (Matheke and Horner, 1974).

From our initial studies on the epontic ice fauna in Stefansson Sound, we have concluded that the nearshore ice meiofaunal assemblage is derived from both the pelagic and benthic biota and that it is probably transitory and changeable in nature. Because of the large proportion of larval and young benthic forms it is suggested that the epontic underice community is an alternate pathway unique to the sea ice zone for certain species to recruit into the benthic community. The sea ice provides a substrate that has a large food source early in the arctic spring season. However, the ice meiofauna themselves are probably not abundant enough to be a significant factor in the lagoonal food web and energy budget.

Acknowledgements. We thank P. H. Scott for laboratory assistance; B. C. Coull and R. E. Ruff, for aid in taxonomic matters; K. Dunton, G. F. Smith, J. Olson and P. Plesha, for diving support. W. G. Pearcy and L. F. Small critically reviewed an earlier version of the manuscript; R. E. Ruff, E. W. Hogue, K. Walters, P. H. Scott and 3 anonymous reviewers made helpful comments. This study was funded by the Bureau of Land Management through interagency agreement with the National Oceanic and Atmospheric Administration as part of the Outer Continental Shelf Environmental Assessment Program.

\section{LITERATURE CITED}

Alexander, V. (1974). Primary productivity regimes of the nearshore Beaufort Sea, with reference to potential roles of ice biota. In: Reed, J. C., Sater, J. E. (eds.) The Coast and shelf of the Beaufort Sea. Arctic Inst. North America, Arlington, pp. 609-632

Alexander, V. (1980). Interrelationships between the seasonal sea ice and biological regimes. Cold Regions Sci. and Technol. 2: 157-178

Andriashev, A. P. (1968). The problems of the life community associated with the Antarctic fast ice. In: Currie, R. I. (ed.) Symposium of antarctic oceanography. Scott Polar Research Institute, Cambridge, pp. 147-155

Andriashev, A. P. (1970). Cryopelagic fishes of the Arctic and Antarctic and their significance in polar ecosystems. In: Holdgate, M. W. (ed.) Antarctic ecology, Vol. I. Academic Press, London, New York, pp. 297-304

Apollonio, S. (1965). Chlorophyll in arctic sea ice. Arctic 18: 118-122

Barnard, J. L. (1959). Epipelagic and under-ice Amphipoda of the Central Arctic Basin. In: Sci. Studies, Fletcher's Ice Island T3 (1952-1955), No. 1 Geophysical Res. Paper No. 63: 115-152

Barnes, P., Fox, D., Reimnitz, E. (1979). Sediment load carried by seasonal ice off northern Alaska, 1979. (Abstr.) Abstracts with Program, Geological Society of Ameria Ann. Meet. Vol. 11(7): 384
Bell, S. S., Sherman, K. M. (1980). A field investigation of meiofaunal dispersal: tidal resuspension and implications. Mar Ecol. Prog. Ser 3: 245-249

Blake, J. A. (1975). The larval development of Polychaeta from the northern California coast. III. Eighteen species of Errantia. Ophelia 14: 23-84

Broad, C. (1979). Environmental assessment of selected habitats in the Beaufort and Chukchi littoral system. In: Environmental assessment of the Alaskan Continental Shelf, Annual Rp. 1979. NOAA/OCSEAP, Boulder, Colorado, pp. 360-542

Clasby, R. C., Alexander, V., Horner, R. (1976). Primary productivity of sea-ice algae. In: Hood, D. W., Burrell, D. C. (eds.) Assessment of the Arctic marine environment. Inst. Mar. Science, University of Alaska, Fairbanks. Occ. Pub. 4: $289-304$

Coull, B. D., Bell, S. S. (1979). Perspectives of marine meiofaunal ecology. In: Livingston, R. J. (ed.) Ecological processes in coastal and marine systems. Plenum Publishing Corp., New York, pp. 189-216

Dunbar, M. J. (unpubl. ms). Fauna associated with ice diatoms in the Arctic and Antarctic

Dunbar, M. J., Acreman, J. C. (1980). Standing crops and species composition of diatoms in sea ice from Robeson Channel to the Gulf of St. Lawrence. Ophelia 19: 61-72

English, T. S. (1961). Some biological oceanographic observations in the Central North Polar Sea. Drift Station Alpha, 1957-58. Arctic Inst. N. Am., Sci. Rp. 15

Fauchald, K., Jumars, P. A. (1979). The diet of worms: a study of polychaete feeding guilds. Oceanogr. mar. Biol. A. Rev. 17: 193-284

Fenchel, T., Lee, C. C. (1972). Studies on ciliates associated with sea ice from Antarctica. I. The nature of the fauna. Arch. Protistenk. 114: 231-236

Golikov, A. N., Averincev, A. G. (1977). Distribution patterns of benthic and ice biocenoses in the high latitudes of the polar basin and their part in the biological structure of the world ocean. In: Dunbar, M. J. (ed.) Polar oceans. Arctic Inst. North America, Calgary, Alberta, pp. 331-364

Hauspie, P., Polk, P. H. (1973). Swimming behavior patterns in certain benthic harpacticoids. Crustaceana 25: 95-103

Hentschel, E. (1922). Über den Bewuchs auf den treibenden Tangen der Sargassosee. Jb. hamb. wiss. Anst. 38 (Beiheft): $1-26$

Hesse, R., Allee, W. C., Schmidt, K. P. (1951). Ecological animal geography, John Wiley and Sons, New York

Horner, R. A. (1976). Sea ice organisms. Oceanogr. Mar. Biol. A. Rev. 14: 167-182

Horner, R. A. (1977). History and recent advances in the study of ice biota. In: Dunbar, M. J. (ed.) Polar oceans. Arctic Inst. North America, Calgary, Alberta, pp. 269-284

Horner, R. (1981). Beaufort Sea plankton studies: winterspring studies in Stefansson Sound and off Narwhal Island, Nov. 1978-Jan. 1980. Final Report. NOAAOCSEAP Contract \#03-78-B01-6. 31 Mar. 1980

Horner, R. A., Alexander, V (1972). Algal populations in arctic sea ice: an investigation of heterotrophy. Limnol. Oceanogr. 17: $454-458$

Hsiao, S. E. C. (1980). Quantitative composition, distribution, community structure and standing stock of sea ice microalgae in the Canadian Arctic. Arctic 33: 768-793

McIntyre, A. D. (1969). Ecology of marine meiobenthos. Biol. Rev. 44: 245-290

Mohr, J. L., Tibbs, J. (1963). Ecology of ice substrates. In: Arctic Inst. North America. Proceedings of the Arctic Basin symposium. Tidewater Publishing Corp., Centerville, Md., pp. 245-249 
Montagna, P. A., Carey, A. G., Jr. (1978). Distributional notes on Harpacticoida (Crustacea: Copepoda) collected from the Beaufort Sea (Arctic Ocean). Astarte 11. 117-122

Percy, J. A. (1975). Ecological physiology of arctic marine invertebrates. Temperature and salinity relationships of the amphipod Onisimus affinis H. J. Hansen. J. exp. mar. Biol. Ecol. 20: 99-117

Sars, G. O. (1918). Crustacea of Norway, Vol. VI, Bergen Museum, Alb. Cammermeyer's Forlag, Christiana, pp. 11-12
Sherman, K. M., Coull, B. C. (1980). The response of meiofauna to sediment disturbance. J exp. mar. Biol. Ecol. 47 : 59-71

Thorson, G. (1946). Reproduction and larva development of Danish marine bottom invertebrates, with special reference to the planktonic larvae in the Sound (Øresund). Meddr Kommn Danm. Fisk.-og Havunders. (Ser. Plankton) $4: 1-523$

This manuscript was submitted to the editor; it was accepted for printing on December 11,1981 